\title{
Can a New Concept of Control under IFRS Have an Impact on a CCCTB?*
}

\author{
Libor Vašek ${ }^{*}$-Tereza Gluzová ${ }^{* *}$
}

\section{Introduction}

The Common Consolidated Corporate Tax Base (CCCTB) is a single set of rules that companies operating within the European Union (EU) could use to calculate their taxable profits. In other words, a company or qualifying group of companies would have to comply with just one EU system for computing its taxable income, rather than different rules in each Member State in which they operate. In 2011, the European Commission issued the Proposal for a Council Directive on a CCCTB that has not been concluded in final issue of the Directive yet. However, there are lots of discussions across the Member States. We contribute to this discussion by assessing, whether changes in financial reporting standards regarding the definition of a consolidated group can affect the determination of consolidated corporate tax base. The further goal of the paper is to evaluate the impact of introduction of CCCTB on the informational content of financial statements.

The goal of the common income tax system is to substantially decrease administrative burden and related costs that incurred in relation to apply various tax legislation if the group of companies operates in several countries within the EU. The idea of the CCCTB can be compared with a decision to apply IFRS across the EU by all publicly traded companies. Currently, there is a common accounting system for all European publicly traded companies that shall prepare

This article has been prepared under the research project Assumptions for Introduction of the IFRS as an Alternative Tax Base in a Small Open Economy: Evaluation of Its Impact on Country's Competitiveness supported by the Czech Science Foundation under the registration number P403/12/1901.

* Ing. Libor Vašek, Ph.D. - Lecturer; Department of Financial Accounting and Auditing, Faculty of Finance and Accounting, University of Economics, Prague, W. Churchill Sq. 4, 13067 Prague 3, Czech Republic; 〈vasek@vse.cz>.

** Ing. Tereza Gluzová - Ph.D. Student; Department of Financial Accounting and Auditing, Faculty of Finance and Accounting, University of Economics, Prague, W. Churchill Sq. 4, 13067 Prague 3, Czech Republic; <xglut00@vse.cz>. 
and present their financial statements in accordance with the IFRS. If we consider an European group that prepare consolidated financial statements under the IFRS, can we expect any impact on taxation in a mode of the CCCTB (based on a proposal) due to a new concept of control which is for European companies effective in IFRS since 1 January 2014? This question reacts on a fact that in May 2011 new standards of the IFRS regarding concept of control and related disclosure requirements were issued. An adoption of the new standards has raised lots of questions whether a scope of a consolidation (a group of some reporting entity) will be changed based on new concept of the control (whether more or less entities will be consolidated). The change in the concept of control may introduce an additional stream of measures to manage earnings for taxation purposes. The risk of tax avoidance increases taking into account that inclusion/exclusion of particular companies in consolidated corporate tax base may depend entirely on requirements of financial reporting standards, if taxation rules would follow accounting definition of control. As the new standards will be effective in the EU from 1 January 2014, the final conclusions cannot be made sooner than in 2015. However, reliable expectation can already be expressed referring to the preliminary disclosure included in the financial statements of 2013 by those companies, which decided to apply corresponding standards earlier.

\section{Background of the CCCTB as a phenomena of future European income taxation}

Despite the CCCTB was formally proposed in March 2011 when the European Commission issued the Proposal for a Council Directive on a CCCTB (COM (2011) 121/4), the idea was established ten years ago. In 2001, the European Commission issued the Communication file called "Towards an Internal Market without tax obstacles - A strategy for providing companies with a consolidated corporate tax base for their EU-wide activities". Since that time lots of working papers and opinions about possible approaches (scenarios) how to adopt the CCCTB in the EU including pros and cons assessment were published (Kubátová, 2007). Simultaneously, a relation between possible CCCTB and already in the EU adopted IFRS has been interesting topic (Schön, 2004; Oestreicher - Spengel, 2007; Essers, 2009 ) if we consider that there is always certain level of relation and influence between accounting (and resulted financial reporting) and taxation. In many countries including the Czech Republic, the tax base 
is directly derived from the accounting profit (Jirásková - Molín, 2013).

The European Commission believes that the only systematic way to address the underlying tax obstacles, which exist for companies operating in more than one Member State in the Internal Market, is to provide companies with a consolidated corporate tax base for their EUwide activities. The proposed Common Consolidated Corporate Tax Base (CCCTB) would mean that companies would benefit from a "one-stop-shop" system for filing their tax returns and would be able to consolidate all the profits and losses they incur across the EU. Groups using the CCCTB would thus be able to file a single consolidated tax return for their entire activity in the EU. Since the Member States would maintain their full sovereign right to set their own corporate tax rate, the consolidated taxable profits of the group would be shared out to the individual companies by a simple formula which is clearly proposed in exposure draft of the Council Directive. A description of the proposed Council Directive and its possible effect on the European companies is analysed e.g. by Trezziova (2011) or Jirásková (2013).

Based on the proposal the tax group should include parent company (which is reporting entity of the consolidated financial statements) and qualifying subsidiaries that are all direct or in-direct subsidiaries in which parent companies holds:

- a right to exercise more than $50 \%$ of the voting rights; and

- an ownership right amounting to more than $75 \%$ of the company`s capital or more than $75 \%$ of the rights giving entitlement to profit.

These thresholds are met at least nine consecutive months. The parent and the qualifying subsidiaries create a tax group and their tax bases are consolidated which means an aggregation of all revenues and expenses, elimination of all intra-group transactions. The rules defines consolidated group for determination of consolidated tax base independently on financial reporting standards. Therefore, the space for manipulation of taxable profit by managing the structure of consolidation group abusing accounting principles is limited.

Based on the analysis above that mutual relationship between CCCTB and financial reporting (in terms of definition consolidation group) seems to be independent, as separate definitions are applied for taxation purposes. On the other side, different definitions may lead to a 
different scope of consolidated companies for taxation and financial reporting. This may hamper the understandability of financial statements for external users, as some subsidiaries included in consolidated financial statements may not qualify for the inclusion in consolidated corporate tax base and vice versa. Furthermore, the principles of tax consolidation are similar to a consolidation for financial purposes regardless a particular accounting system adopted by entities. However, a logical question related to a use of the CCCTB that has been raised is "What accounting system should be used by entities that have decided to use the CCCTB for income taxation?" Shall all members of a tax group obligatory apply e.g. the IFRS (i.e. common accounting system for all entities)? What would happen, if taxation were based on IFRS (Jacobs et al., 2005; Eberhartinger Klostermann, 2007)? Can changes (amendments) in the IFRS such as a change of control concept have impact on the calculation of income tax in the mode of the CCCTB?

\section{Concept of control in IFRS and expectation of publicly traded companies regarding new concept and related disclosures}

The basic principle of consolidation in the IFRS is to consolidate all entities (subsidiaries) that are controlled by parent company (investor). Currently under IFRS 10 Consolidated financial statements, effective since 1 January 2013 (and for European companies since 1 January 2014), "An investor controls an investee when the investor is exposed, or has rights, to variable returns from its involvement with the investee and has the ability to affect those returns through its power over the investee." Till the end of 2012, the control in the IFRS used to be defined in IAS 27 Consolidated and separate financial statements as "the power to govern the financial and operating policies of an entity so as to obtain benefits from its activities". Furthermore, there was also the interpretation for special purposes entities (SIC-12 Consolidation - Special purposes entities) with different view on control. This inconsistency between IAS 27 and SIC-12 was obvious because the IASB as the responsible body for the IFRS added the project on consolidation to its agenda already in 2002. However, the exposure draft of the amendments was issued in December 2008 after several corporate scandals when some entities were not included in the scope of the group`s consolidation and were used to hide losses. 
The concept of control in the IFRS (and also in the U.S. GAAP or other national accounting systems) has been developed for a long time (Kořínek, 2012) and several concepts of control are generally distinguished in theory (Muller - Cardos - Ienciu, 2010). The new concept of control should push away most of problems that were brought to light in the past years. The new concept of control is also an outcome of a convergence project between the IASB and the FASB (responsible body for the U.S. GAAP) that also issued amendments. As a consequence of this project existing differences between the IFRS and the U.S. GAAP are currently eliminated.

As was already mentioned above, the new standards - specifically IFRS 10 and IFRS 12 Disclosure of interests in other entities - are mandatory effective since reporting period beginning on 1 January 2013 except for countries within European Union. Since we are discussing an influence of the IFRS on the income taxation within the $\mathrm{EU}$, we have to stress that effectiveness of these standards begun for all European companies on 1 January 2014, one year later than official date approved by the IASB. Most of European companies did not decide to apply these amendments early, already for 2013 or 2012. Therefore, the year 2014 is the first year in which new standards are applied by all entities regardless they domicile. Furthermore, the first half of 2015 is going to be a perfect period for an analysis of a final impact of new concept of control on the financial reporting.

Generally, based on the idea of the project that new concept of control will eliminate existing problems, we should expect that the new concept of control will influence a determination of each scope of a consolidation and probably some reporting entities shall consolidate more entities that they used to do. However, the introduction of the new rules is always partly "a step into the unknown," which in this case is enhanced by a number of subjective judgments that the entities are required to make by the new standards. Therefore, the new concept of the control can be applied by various entities in different way and also a reduction of the scope of a consolidation is possible.

Since the final annual consolidated financial statements affected by new concept will be published in early 2015, we can express some expectations based on information disclosed in consolidated financial statements for 2013 in which disclosure of relevant information is required by IAS 8 Accounting policy, changes in accounting estimates and errors. To illustrate the (expected) impact of IFRS 10 we 
considered companies with shares traded on the main market of the Prague Stock Exchange (PSE) and analysed their expectations expressed in their last consolidated financial statement. All these companies shall prepare and disclose financial statements according to the IFRS and we focused on whether the company decided for early application of the standards or not. In case that some entities have already adopted IFRS 10, we were interested in effects of that application. In case of all other entities that not applied IFRS 10 earlier, we examined expected impacts.

Tab. 1: Impacts of IFRS 10 analysed on companies with shares traded on Prague stock exchange

\begin{tabular}{|l|c|c|c|c|}
\hline \multicolumn{1}{|c|}{ Company } & $\begin{array}{c}\text { Balance } \\
\text { sheet date }\end{array}$ & $\begin{array}{c}\text { Adoption } \\
\text { of IFRS } \\
\mathbf{1 0}\end{array}$ & $\begin{array}{c}\text { Expected } \\
\text { effects }\end{array}$ & $\begin{array}{c}\text { No. of } \\
\text { subsidiaries }\end{array}$ \\
\hline $\begin{array}{l}\text { Borealis } \\
\text { Exploration LTD }\end{array}$ & 31.3 .2013 & $\begin{array}{c}\text { Not } \\
\text { mentioned }\end{array}$ & $\begin{array}{c}\text { Not } \\
\text { disclosed }\end{array}$ & 19 \\
\hline ČEZ a.s. & 31.12 .2012 & 2014 & $\begin{array}{c}\text { Not } \\
\text { expected } \\
\text { any effects }\end{array}$ & 91 \\
\hline $\begin{array}{l}\text { Erste Group Bank } \\
\text { AG }\end{array}$ & 31.12 .2013 & 2014 & $\begin{array}{c}\text { Expected } \\
\text { but not } \\
\text { specified }\end{array}$ & 258 \\
\hline $\begin{array}{l}\text { Fortuna } \\
\text { Entertainment } \\
\text { Group N.V. }\end{array}$ & 31.12 .2013 & 2013 & $\begin{array}{c}\text { Without } \\
\text { effects }\end{array}$ & 12 \\
\hline Komerční banka a.s. & 31.12 .2012 & 2014 & $\begin{array}{c}\text { Not } \\
\text { expected } \\
\text { any effects }\end{array}$ & 8 \\
\hline $\begin{array}{l}\text { New World } \\
\text { Resources Plc }\end{array}$ & 31.12 .2013 & 2014 & $\begin{array}{c}\text { Not } \\
\text { expected } \\
\text { any effects }\end{array}$ & 5 \\
\hline $\begin{array}{l}\text { Orco Property } \\
\text { Group S.A. }\end{array}$ & 31.12 .2013 & 2013 & $\begin{array}{c}\text { Without } \\
\text { effects }\end{array}$ & 67 \\
\hline $\begin{array}{l}\text { Pegas Nonwovens } \\
\text { SA }\end{array}$ & 31.12 .2013 & 2014 & $\begin{array}{c}\text { Not } \\
\text { expected } \\
\text { any effects }\end{array}$ & 5 \\
\hline
\end{tabular}


Vašek, L. - Gluzová, T.: Can a New Concept of Control under IFRS Have an Impact on a CCCTB?

\begin{tabular}{|l|c|c|c|c|}
\hline Company & $\begin{array}{c}\text { Balance } \\
\text { sheet date }\end{array}$ & $\begin{array}{c}\text { Adoption } \\
\text { of IFRS } \\
\mathbf{1 0}\end{array}$ & $\begin{array}{c}\text { Expected } \\
\text { effects }\end{array}$ & $\begin{array}{c}\text { No. of } \\
\text { subsidiaries }\end{array}$ \\
\hline $\begin{array}{l}\text { Telefonica Czech } \\
\text { Republic a.s. }\end{array}$ & 31.12 .2012 & 2014 & $\begin{array}{c}\text { Not } \\
\text { expected } \\
\text { any effects }\end{array}$ & 5 \\
\hline $\begin{array}{l}\text { Tatry Mountain } \\
\text { Resort a.s. }\end{array}$ & 31.10 .2013 & $10 / 2014$ & $\begin{array}{c}\text { Under } \\
\text { analysis }\end{array}$ & 5 \\
\hline UNIPETROL a.s. & 31.12 .2013 & 2014 & $\begin{array}{c}\text { Not } \\
\text { expected } \\
\text { any effects }\end{array}$ & 19 \\
\hline VGP NV & 31.12 .2013 & 2014 & $\begin{array}{c}\text { Not } \\
\text { expected } \\
\text { any effects }\end{array}$ & 29 \\
\hline $\begin{array}{l}\text { Vienna Insurance } \\
\text { Group }\end{array}$ & 31.12 .2013 & 2014 & $\begin{array}{c}\text { Not } \\
\text { expected } \\
\text { any effects }\end{array}$ & 121 \\
\hline
\end{tabular}

Source: Authors' processing.

The only one of the thirteen companies that all publish consolidated financial statements in accordance with the IFRS observes that the transition to IFRS 10 will affect its accounting and related financial reporting - the Erste Group Bank AG ("Erste"), which is also the largest of all companies surveyed. Since 1 January 2014, Erste will consolidate the investment funds, in which Erste (one of all entities within the group) operates as the manager. These investment funds were not consolidated in previous years because conditions and requirements of SIC-12 were not met. Furthermore, Erste assesses whether the new concept of control will also affect managed pension funds. Since their business is highly regulated, the assessment has not been concluded. All other companies stated that they do not expect any impact on their consolidated financial statements in connection with the adoption of IFRS 10.

The IASB permitted IFRS 10 to be adopted early before 1 January 2013 that is quite general principle applied almost in all new standards and amendments. If we consider this possibility in relation to companies mentioned in the table above only two of them adopted IFRS 10 earlier and they both disclosed that there is no affect on the financial situation and performance. Before the IASB issued IFRS 10 
and related standards (IFRS 11 Joint arrangements, IFRS 12, amendments on IAS 27 Separate financial statements, IAS 28 Investments in associates and joint ventures) lots of issues had been discussed between the IASB and both the reporting entities that prepared consolidated financial statements and the users of the financial statements. The conclusions of the "round tables" are summarized in the study of expected impacts. The study answers the most frequent questions - whether IFRS 10 introduces absolutely new requirements on consolidation and whether its adoption will enhance scope of the consolidated entities. The IASB states that in many cases current adoption of IFRS 10 will have the same impact as previous adoption of IAS 27 and SIC-12. The benefit of the new control concept is a fact that principles and specific judgements are more that some numerical measures (e.g. the majority votes) and they should ensure better information provided to users - they will know all about entities that are controlled regardless if they are also owned.

A comprehensive study (2012a and 2012b) was also made by European Financial Reporting Advisory Group (EFRAG) that was in a form of a questionnaire. EFRAG asked companies to express their expectations regarding an adoption of IFRS 10 and related standards and how difficult for them will be an implementation of the new requirements into practice. The first study "Feedback report on fieldtests on IFRS 10, IFRS 11 and IFRS 12" was focused on the new standards in general and 27 companies participated on the part relating to IFRS 10. The second study "Supplementary study - Consolidation of Special Purpose Entities (SPEs) under IFRS 10" was concerned solely a consolidation of SPEs / structured units and resulting changes -14 companies were involved.

If we summarize both studies together with financial statements already prepared in accordance with IFRS, the most significant changes are as follows:

\section{1. "De facto" control}

$70 \%$ companies stated they had not applied the concept of „de facto" control (EFRAG, 2012a) and they do not expect any effect on financial statements from this amendment. The companies appreciate illustrative examples that are provided in IFRS 10 but they worry whether they are able to get all information needed to assess all relevant aspects of „,de facto“ control. 


\subsection{Delegated management (Principal vs. Agent)}

The issue of delegated management that is newly included in the IFRSs should relate mainly to banks and other financial institutions. $50 \%$ of respondents have an opinion that putting this requirement into practise is challenging and primarily these aspects should be considered:

- There are no clear numerical limits and various entities can conclude same situation differently;

- If equity interests are dispersed among lots of small investors, entities do not have access to all information; e.g. they are not able to know if there are some agreements among investors;

- Use of subjective judgements in assessment of variable returns companies point out that illustrative examples included in IFRS 10 solve only basic situations and do not provide clear illustration for complex real cases. Therefore, companies are not sure how to apply IFRS 10 in such complex cases.

\subsection{Structured entities}

The amended principles and requirements for consolidation of structured entities are probably the most significant change provided by IFRS 10. It will require companies to consolidate entities that were out of scope under SIC-12 but on the other hand some companies will not be consolidated any more even they were in the scope for previous periods. We guess that the impact on the numbers in the financial statements will not be too significant for two reasons. Firstly, there is limited number of companies that are really involved in structured entities - typically banks, insurance companies or investment companies. Secondly, total assets (or equity plus liabilities) of structured entities are not material in comparison with total consolidated assets (or equity plus liabilities). If we use figures included in the study of the EFRAG (2012b), only 7 companies surveyed were associated with 10537 structured entities. When they adopt IFRS 10 they will newly consolidate 243 entities but 193 entities will not be longer included in the group - the net increase is only 50 entities and it should lead to increase total assets by $0.06 \%$ - final effect can be considered as not material. 
What structured entities should be affected by current changes in the IFRS? Based on information answered by the respondents in the study, following aspect should be considered:

- Less emphasis on the benefits and risks of the entity when an exposure to majority of the benefits and risks is not considered as a condition of consolidation; based on this change, some investments funds and similar securitized entities should be newly consolidated;

- Different approach to the rights of remove;

- Provisions for the delegated management that require companies to examine whether they are in the position of an agent in other companies and if yes these entities are not consolidated because there is not control under IFRS 10;

- Assessment how and by whom relevant activities of the entity are managed which mean that a company without a possibility to influence relevant activities of the entity cannot exercise a control even this company is exposed to the benefits and risks. The companies state that this point will cause a deconsolidation of certain structured entities - mainly from the area of securitization, asset transfers or leases.

Based on EFRAG studies`outcomes and our analysis of companies traded on PSE a quite clear conclusion regarding Czech traded entities can be made - these entities do not expect material effect resulting from the adoption of IFRS 10 on their consolidated financial statements. IFRS 10 will have an effect on limited scope of companies - mainly on banks, insurance companies and other financial institutions.

However, what is generally expected that will have significant effect on financial statements is an extent of disclosure provided in the notes. It is an inherent consequence of the new standard - IFRS 12 and it will affect not only subsidiaries but also interests in other entities. Companies report that the adoption of IFRS 12 will substantially increase the amount of information included in the financial statements. The concerns are expressed particularly in relation to participation in structured entities - companies are in doubts if they are able to get all necessary information in time. They also lack a precise interpretation of certain terms (such as "sponsor"). 
IFRS 12 emphasizes that a goal is certainly not overwhelm the notes by excessive details in which are users lost. In paragraph B2 the standard precisely states: "An entity shall decide, in the light of its circumstances, how much detail it provides to satisfy the information needs of users, how much emphasis it places on different aspects of the requirements and how it aggregates the information. It is necessary to strike a balance between burdening financial statements with excessive detail that may not assist users of financial statements and obscuring information as a result of too much aggregation." The decision how much detailed information will be disclosed is kept in companies' hands. Various companies will solve the same case differently. Detailed disclosure is required for participation in structured entities that are more common for financial institutions such as banks, insurance companies, and not for production companies. Therefore, the extent of disclosure will be greater for the banks etc. Is this assumption and expectation right?

To illustrate the impact of IFRS 12 we used financial statements of four European entities that adopted IFRS 12 earlier, already for 2013 two banks and two production companies. The table below shows a comparison of the extent of information provided in relation to interests in other entities disclosed in the notes to the financial statements in 2013 (affected by adoption of IFRS 12) and 2012 (based on requirements effective before IFRS 12):

Tab. 2: Disclosure of interests in other entities based on IFRS 12

\begin{tabular}{|c|c|c|c|c|}
\hline \multirow[b]{2}{*}{ Company } & \multirow{2}{*}{$\begin{array}{l}\text { No. of } \\
\text { subsidiarie } \\
\qquad S\end{array}$} & \multirow{2}{*}{$\begin{array}{l}\text { No. of pages } \\
\text { of notes to } \\
\text { consolidated } \\
\text { financial } \\
\text { statements } \\
\text { (current } \\
\text { year 2013) }\end{array}$} & \multicolumn{2}{|c|}{$\begin{array}{c}\text { Disclosure of interests in other } \\
\text { entities } \\
\text { (no. of pages) }\end{array}$} \\
\hline & & & $\begin{array}{c}\text { Current year } \\
2013 \\
\text { (adopted } \\
\text { IFRS 12) }\end{array}$ & $\begin{array}{l}\text { Current year } \\
2012 \\
\text { (not adopted } \\
\text { IFRS 12) } \\
\end{array}$ \\
\hline $\begin{array}{c}\text { Deutsche } \\
\text { Bank }\end{array}$ & 2171 & 158 & 6 & 4 \\
\hline Barclays & 1213 & 83 & 10 & 4 \\
\hline Volvo & 310 & 48 & 6 & 4 \\
\hline $\begin{array}{l}\text { Arcelor } \\
\text { Mittal }\end{array}$ & 35 & 89 & 9 & 3 \\
\hline
\end{tabular}

Source: Authors' processing. 
We are aware that the financial statements of four companies cannot be considered as fully representative sample. Nevertheless, some conclusions regarding impact of IFRS 12 on future consolidated financial statements can be expressed:

1. An extent of the disclosure was raised as a consequence of the adoption of IFRS 12 in all four financial statements analysed. However, each company treats the requirements of the standard differently and therefore, there are differences in the amount of information provided, in its format and content.

ArcelorMittal prefers to include all disclosed information in one section and its financial statements contain a new section 12 described as "Investments in subsidiaries, associates and joint arrangements" and also the information about the non-controlling interests and unconsolidated structured entities are contained in this section.

Other companies disclose information using a number of discrete notes such as Volvo: Note 5 - Investments in jointly controlled entities, associates and other investments and participation, Note 11 - Non-controlling interests. The subsidiaries are disclosed in relation to separate financial statements in the Note 13 investments in shares and interest and significant limitations on the transfer of assets of subsidiaries are included in the note regarding disclosure of cash and cash equivalents.

2. Either the number of companies in the group or extent of the notes is not an indication of detailed disclosure. Deutsche Bank with more than two thousand subsidiaries (of which 1468 are structured entities) discloses required information using only six pages of the notes. In contrary, ArcelorMittal uses $10 \%$ of the notes for this disclosure.

3. Judgments used to determine "control" in other companies are described often somewhere in the beginning of the notes and relevant section is usually limited on definition of control included in IFRS 10. Barclays Bank is an exemption and provides relevant information in the note regarding subsidiaries.

4. Extended disclosures resulting from the adoption of IFRS 12 include substantially more detailed description of the numerical values (assets, liabilities, revenue, expenses etc.) of subsidiaries with material non-controlling interests - this requirement has 
touched all companies except for Deutsche Bank in whose consolidated financial statements material non-controlling interests are not recognised and presented.

5. Only Barclays provides much more detailed description of the risks associated with interests in consolidated structured entities in its consolidated financial statements. New disclosure regarding unconsolidated structured entities was included in the notes to financial statements by all companies except for Volvo. Volvo apparently has no such interests because nothing about structured entities is mentioned in its financial statements.

When we compare financial statements of banks (Deutsche Bank and Barclays) with production companies (Volvo and ArcelorMittal) effect on financial statements resulting from IFRS 12 is obvious for the financial institutions. Deutsche Bank added a new note 40 - Unconsolidated structured entities and provides detailed relevant descriptions in four pages. Barclays provided information about off-balance sheet arrangements including special purpose entities (SPE) in the financial statements for 2012. As a consequence of the adoption of IFRS 12, Barclays's interests in structured entities are described over six pages of the notes. In contrary, ArcelorMittal needed only two pages to disclose all required information.

\section{Level of a relation between the IFRS and the CCCTB}

Despite the IFRS represent a common base for financial reporting across the EU (at least for publicly traded European companies) since 2005 and this quite successful project could be originally an idea for the CCCTB, the Proposal for a Council Directive on a CCCTB issued by the European Commission in 2011 includes an own concept of a calculation of the tax base, which is independent on any accounting system including the IFRS. The CCCTB shall be calculated as revenues less exempt revenues, deductible expenses and other deductible items and all exempt and deductible items are written directly in the Proposal. Therefore, the accounting net income is not a base from which tax base is derived like in the Czech Republic and changes in accounting rules should not affect tax base significantly. The concept of control and its current change in the IFRS should not have any impact on the taxation using the CCCTB because there are also different rules (mentioned earlier in the text) how to determine tax 
group for the tax purposes. Although expectations regarding an initial adoption of the new concept of control are quite positive (no changes expected) this fact should be neutral for income taxation under the CCCTB.

\section{Conclusion}

The Common Consolidated Corporate Tax Base (CCCTB) is a single set of rules that companies operating within the European Union (EU) could use to calculate their taxable profits. This possible future income taxation is based on a determination of tax group, which is defined directly in the Proposal for the Council Directive, and there is no influence of any accounting system including the IFRS and other national rules. Therefore, a change of the control concept issued in the IFRS and effective since 2014 cannot affect a determination of the tax group. Furthermore, if we compare both definitions of the group we can conclude that the tax group should include less companies that a group for financial purposes because not all subsidiaries can be considered in the tax group due to quite strict conditions. The use of the CCCTB should also be independent on accounting system applied by individual entities within the tax group. Following an issue of the Proposal there has been a decision not to make an obligatory link between the CCCTB and the IFRS financial statements. Therefore, the European companies might prepare their consolidated financial statements under German GAAP, Dutch GAAP or Czech GAAP etc. Finally based on two main factor mentioned above, we can express that the use of the CCCTB cannot be influence by any amendments issued in the IFRS. This approach could be also considered as a good concept how to establish new rules for income taxation of Czech companies that apply the IFRS in accordance with the Czech Accounting Act but they shall also determine net income based on rules of the Czech accounting legislation (not the IFRS) for tax purposes.

Furthermore, we analysed expectations regarding the impact of IFRS 10 on companies that are traded on the main market of the Prague Stock Exchange. Based on the analysis, the only one of the thirteen companies that all publish consolidated financial statements in accordance with IFRS observes that the transition to IFRS 10 will affect its accounting and related financial reporting. - Erste Group Bank AG. This conclusion equals to conclusions resulting from the IASB's study - in many cases current adoption of IFRS 10 will have 
the same impact as previous adoption of IAS 27 and SIC-12. The benefit of the new control concept is a fact that principles and specific judgements are more that some numerical measures (e.g. the majority votes) and they should ensure better information provided to users they will know all about entities that are control regardless if they are also owned. We summarized that the most significant changes resulting from new standards are (i) "de facto" control, (ii) delegated management (principal vs. agent) and (iii) structured entities. We also analysed an impact of IFRS 12 using financial statements of four European entities that adopted IFRS 12 earlier, already for 2013 - two banks and two production companies. When we compare financial statements of banks (Deutsche Bank and Barclays) with production companies (Volvo and ArcelorMittal) effect on financial statements resulting from IFRS 12 is obvious for the financial institutions. However, we can conclude this expectation that notes to the consolidated financial statements will be extended in all cases. This analysis should continue next year as soon as consolidated financial statements for 2014 are issued. We will be able to compare current expectation with final reality and make a conclusion about an impact of new IFRS concept of control on financial reporting

\section{References}

Eberhartinger, E. - Klostermann, M. (2007): What if IFRS were a Tax Base? New Empirical Evidence from an Austrian Perspective. Accounting in Europe, 2007, vol. 4, no. 2, pp. 141-168.

Essers, P. (2009): The Influence of IAS/IFRS on the CCCTB, Tax Accounting, Disclosure and Corporate Law Accounting Concepts: a Clash of Cultures. Alphen aan den Rijn: Kluwer law international.

Jacobs, O.H. - Spengel, C. - Stetter, T. - Wendt, C. (2005): EU Company Taxation in Case of a Common Tax Base. Discussion Paper no. 05-374. 2005. Centre for European Economic Research.

Jirásková, S. (2013): Taxation under the CCCTB. In: PROCHÁZKA, David (ed.). The 13th Annual Doctoral Conference of the Faculty of Finance and Accounting, University of Economics, Prague. Praha, 01.06.2012. Praha: Nakladatelství Oeconomica, 2012, pp. 259-265.

Jirásková, S. - Molín, J. (2013): Impact of the IFRS Adoption for Tax Purposes in the Czech Tax Collection. European Financial and Accounting Journal, 2013, vol. 8, no. 2, pp. 46-60. 
Kořínek, M. (2012): Koncepce ovládání v souvislostech konsolidované účetni závěrky. Diplomová práce. 2012. VŠE v Praze

Kubátová, K. (2007): Korporativní dă̌ v Evropské unii - je harmonizace možná? Manažment hodnoty podniku 2007. Bratislava: Bratislavská vysoká škola práva, 2007, pp. 26.

Muller, V. - Cardos, I. R. - Ienciu, A. I. (2010): Consolidation Policy: Past, Present and Future Approaches to the Concept of Control. The Journal of the Faculty of Economics. University of Oradea. 2010, pp. 541-547

Oestreicher, A. - Spengel, C. (2007): Tax Harmonisation in Europe. The Determination of Corporate Taxable Income in the EU Member States. Discussion Paper No. 07-035. 2007. Centre for European Economic Research.

Schon, W. (2004): International Accounting Standards - A "Starting Point" for a Common European Tax Base? In: European Taxation. 2004.

Trezziova, D. (2011): Evropský společný konsolidovaný základ daně z př́imu právnických osob. In: Bulletin KDP ČR. 05/2011

EFRAG (2012a): Feedback report on field-tests on IFRS 10, IFRS 11, and IFRS 12. [on-line], 2012, [cited 31 ${ }^{\text {th }}$ March 2014]. <www.efrag.org/files/EFRAG\%20public\%20letters/Consolidation/Fee dback_report_on_field_tests_on_IFRS_10_IFRS_11_and_IFRS_12.pd f>

EFRAG (2012b): Supplementary study - Consolidation of Special Purpose Entities (SPEs) under IFRS 10. [on-line], 2012, [cited 31th March 2014]. <www.efrag.org/files/EFRAG\%20Output/SPE_ Supplementary_study_-_EFRAG_secretariat_report.pdf>

IASB (2013a): International Financial Reporting Standards, as issued at 1 January 2013. IFRS Foundation Publications Department, London, 2013. ISBN 978-1-907877-77-3.

Annual report AB Volvo for 2013 and 2012 <www.volvogroup.com/group/global/en-gb/investors/reports/annual_ reports/pages/annual_reports.aspx>

Annual report ArcelorMittal SA for 2013 and 2012 $<$ http://corporate.arcelormittal.com/investors/financial-reports/annualreports> 
Vašek, L. - Gluzová, T.: Can a New Concept of Control under IFRS Have an Impact on a CCCTB?

Annual report Barclays PLC for 2013 and 2012 $<$ http://group.barclays.com/about-barclays/investor-relations/annualreports>

Annual report Deutsche Bank AG for 2013 and 2012 <https://www.db.com/ir/en/content/reports_2013.htm> 


\title{
Can a New Concept of Control under IFRS Have an Impact on a CCCTB?
}

\begin{abstract}
In May 2011, new standards of the IFRS regarding concept of control and related enhanced disclosure requirements were issued. These new standards have being mandatory effective since reporting period beginning on 1 January 2013 except for countries within European Union where effectiveness begun on 1 January 2014, one year later than official date approved by the IASB. An adoption of the new standards has raised lots of questions whether a scope of a consolidation will be changed based on a new concept of the control (whether more or less entities will be consolidated). The paper provides an analysis of expectations that result from financial statements of companies traded on the Prague Stock Exchange. Together with this analysis the paper discussed an issue if a change of control concept in the IFRS can affect a use of the Common Consolidated Corporate Tax Base, which has been a great topic within the European Union. In 2011 the European Commission issued the Proposal for a Council Directive on a CCCTB and established a draft of rules how to consolidate companies within the EU for the tax purposes. Can the tax approach based on the CCCTB be affected by a change in the IFRS such as a change in the concept of control?
\end{abstract}

Key words: IFRS; Concept of Control; CCCTB; Income Taxation.

JEL classification: M41, H25 